Mesdames Walter Wilson, Sam Weinstock, Harvey Ingham, Sam M. Shloss; Messrs. Casper Schenck, Don MeGregor, A. A. Alexander, Harry E. Wilson, John Normile, and H. J. Kroeger.

The Resident Directors and their terms of service have been as follows: Herbert Wright 1918-1924; Wilder Moore 1924-1926 ; Mrs. A. Lillian Edmunds 1926-.

\title{
NEGRO COMMUNITY CENTER BRANCH
}

The largest group of Negroes in Des Moines live in the district in which the Negro Community Center is situated. Another group of considerable size lives on the East Side. Desiring a place where those living on the East Side might meet together, a group of Negro men and women secured a house at 1622 Walker Street, and in 1922 opened the East Side Community Center. The Center served mainly as a meeting place for clubs or groups already organized. Many mothers in the neighborhood, wishing their babies to have the services of a Well Baby Clinic, had taken their babies to the Negro Community Center on the West Side. These mothers, together with other women, asked the Public Health Nursing Association to open a clinic in the East Side Community Center, and thirty-five babies were enrolled on the opening day in 1933.

By means of the support of interested private individuals, the East Side Community Center served its community for five years as an independent institution. However, in the third and fourth years small grants from the Community Chest for coal and rent were required. In 1936 maintenance of the work was taken over by the Community Chest entirely; in the same year the name was changed to Negro Community Center Branch and new quarters were established at 1438 Buchanan Street. The Negro Community Center Board of Directors (see page 187) is responsible for the conduct of the Branch. Miss Roberta L. Maupin is now in charge of the Branch.

A station of the Public Library is located in the building. 
Classes in handeraft are carried on. A chorus class and other groups of children, young people, and older ones as well, meet regularly in the Center.

The great need of the Branch, as of the Negro Community Center, is for more room and better equipment to earry on services which are so much needed and so greatly appreciated by those who use the Center. It is greatly to be desired that Des Moines may in the near future provide better and more adequate meeting places for its Negro eitizens and their children.

The Society for the Diffusion of Useful Knowledge, before which is weekly read a lecture upon the various subjects of the day, though lately established, is progressing and bids fair to become what its title indicates. . . Last night Dr. Reynolds (a gentleman lately arrived from the east, who designs opening a high school in this city) delivered the second lecture of the course, "on the goodness of God as displayed in the science of Chemistry." The discourse was an instructive one, though of but little interest, as most of the experiments failed, in consequence perhaps of the derangement necessarily attending a removal of his apparatus, which is extensive.-Bloomington Herald, December 4, 1840. "Argus", in a regular letter from Burlington.

THE DemocRats Have Lost the privilege of voting against Mr. Clay, the whig candidate for President, and to whom the "settlers on the Black Hawk Purchase" owe a debt that should be paid. The vote of Iowa might have turned the scale against Mr. Clay-yet, for want of that vote, he may become President over the people he has bitterly branded as "Club-Law Men"_-"Lawless Banditti"-and "Iand Pirates!"-Iou:a Territorial Gazette and Advertiser, September $17,1842$. 
Copyright of Annals of Iowa is the property of State of Iowa, by \& through the State Historical Society of Iowa and its content may not be copied or emailed to multiple sites or posted to a listserv without the copyright holder's express written permission. However, users may print, download, or email articles for individual use. 